\title{
Gender and Sexuality Dynamics in Tariffed Sex among Men: Analysis of the Notion of Communities of Practice
}

\author{
Cristiano Hamann ${ }^{1}$ \\ Programa de Pós-Graduação em Psicologia Social e Institucional, Universidade Federal do \\ Rio Grande do Sul, Porto Alegre, RS, Brazil \\ Adolfo Pizzinato \\ Kátia Bones Rocha \\ Pontifícia Universidade Católica do Rio Grande do Sul, Porto Alegre, RS, Brazil
}

\begin{abstract}
The present study analyzes the establishment of communities of practice in the context of tariffed sex exercised by men, focusing on sexuality performances and gender identifications. Was used an approach inspired by the Grounded Theory, through which were held field diaries in tariffed sex settings, narrative interviews with six men who engage in the activity and two managers, respectively, of two specialized places in the Porto Alegre's sexual market, during the year 2015. The corpus was analyzed from a discursive theoretical perspective and was identified dynamics associated with the formation of communities of practice by means of surveillance and correction strategies, in a way that aspects such as corporeal and performative investment updated consumer relations circumscribed in some control dynamics. Power relations are shown in a way of "desexualization" of the client, or the feminization of the male prostitute, so the notion of community does not dissociate from discursive heteronormative aspects.
\end{abstract}

Keywords: Gender, sexuality, male prostitution, communities of practice, grounded theory.

\section{Dinâmicas de Gênero e Sexualidade no Sexo Tarifado entre Ho- mens: Uma Análise por Meio da Noção de Comunidades de Prática}

\section{Resumo}

Este estudo analisa a constituição de comunidades de prática no contexto do sexo tarifado exercido por homens, com foco nos exercícios de sexualidade e identificações de gênero. Utilizou-se de uma abordagem inspirada na Teoria Fundamentada, por meio da qual se realizaram diarios de campo das incursões em ambientes de sexo tarifado, entrevistas narrativas com seis homens que se dedicam a atividade e dois gerentes de duas casas especializadas no mercado de sexo porto-alegrense, durante o ano de 2015. O corpus foi analisado discursivamente e identificaram-se dinâmicas associadas à formação de comunidades de prática pela via de estratégias de vigilância e correção, de modo que aspectos como o investimento corporal e outras dimensões performativas atualizavam relações de consumo circunscritas em algumas esferas de controle. Exercício de poder se mostram pela via da "dessexualização" do cliente, ou da feminilização do garoto de programa, indicando que a noção de comunidade não se dissociava de aspectos discursivos heteronormativos.

Palavras-chave: Gênero, sexualidade, prostituição, homens.

Mailing address: Universidade Federal do Rio Grande do Sul, Instituto de Psicologia, Programa de PósGraduação em Psicologia Social e Institucional, Rua Ramiro Barcelos, 2600, Térreo, Porto Alegre, RS, Brazil 90035-003. E-mail: cristiano.hamann@gmail.com 


\section{Dinámica de Género y Sexualidad en Sexo Tarifado entre Hombres: Um Análises a través del Concepto Comunidades de Práctica}

\section{Resumen}

Este estudio analiza la formación de comunidades de práctica en el contexto del sexo tarifado ejercido por los hombres, centrándose en los ejercicios de la sexualidad y las identificaciones de género. Se utilizó un enfoque inspirado en la teoría fundamentada, a través de la cual se llevó a cabo incursiones de campo en entornos sexuales tarifados, entrevistas narrativas con seis hombres que se dedican a la actividad y dos gerentes de dos casas especializadas en el mercado del sexo durante el año 2015, en Porto Alegre (BR). El corpus ha sido analizado discursivamente e se han identificado dinámicas asociadas a la formación de comunidades de práctica por la vía de estrategias de vigilancia y corrección, de manera que aspectos como la inversión corporal y performativa actualizaban relaciones de consumo circunscriptas en dimensiones de control. Formas de relación de poder se muestran por la vía de la "desexualización" de los clientes, o la feminización del prostituto, de modo que el sentido de comunidad no se disociaba de aspectos heteronormativos.

Palabras clave: Género, sexualidad, prostitución, hombres.

Studies that shed light on prostitution invite us to notice the diversity of possibilities in sexuality practices, their intricate social markers, and the discourses composing the meanings assigned to this performance (Piscitelli, 2014). This is a strategic field of discussion, as prostitution practices allow connections on a complex web that includes gender, work, sexuality, morality, and human rights (Rios, 2012). International studies have mostly been dedicated to mapping prostitution risks, especially in relation to sexually transmitted diseases - such as HIV/AIDS - and their sociodemographic dimensions (Baral et al., 2015).

However, research in the area is still heterogeneous overall, and parts of these studies indicate the field complexity beyond sanitary risk results. Ballester, Salmerón, Gil and Giménez (2014), for instance, observe the fact that variables such as origin, schooling, and sexual orientation are not enough to understand the phenomenon yet are important discussion aspects. Studies developed in Eastern Europe highlight that prostitution connected to bars is related to higher vulnerabilities, such as the abuse of alcohol and illicit drug and situations involving violence, than Internet business (Bar-Johnson \& Weiss, 2015; Niccolai, King, Eritsyan, Safiullina, \& Rusakova, 2013). Another aspect considered is the analysis of HIV infection risk when comparing sexual practices with customers and non-commercial partners (Grov, RodriguezDíaz, Jovet-Toledo, \& Parsons, 2015).

Studies such as those above allow us to identify a dialogue that needs to be deepened between epidemic dimensions and qualitative and contextual considerations, which question the complexity surrounding the daily experiences of tariffed sex and address the need to focus on aspects such as criminalization, work, gender, and sexuality that characterize the possible practices of these men, as well as the itineraries they follow when engaging in sexual commerce. Some qualitative studies on men's prostitution, especially in Brazil, seek to integrate the previously mentioned psychosocial elements. Ethnographic studies, for instance, make it possible to consider men's prostitution in dimensions of sexuality, subjectivity, and territory, pointing to the particularities of their itineraries (Barreto, 2012; Viana, 2010), the places of sexual tourism in relation to different power axes that make abolition perspectives on prostitution complex (Cantalice, 2009), and their bonds with heteronormativity and homonormativity (Pocahy, 2012).

In Brazil specifically, this higher visibility may be associated with the political rise of Gender Studies, which tries to comprehend the pluralities of "being a man" in today's world and their relationship with asymmetrical systems 
of power in the scope of human relations (Medrado \& Lyra, 2008; Piscitelli \& Simoni, 2015). However, the field of discussion on prostitution is mainly focused on women's experiences (especially cisgender). Although the reflection on women's experiences with prostitution is obviously important, as it can highlight discourses in favor and against (Melo Pedroso, 2015; Piscitelli, 2012), it is also important to notice men's peripheral position in this field of study. Considering this situation, we seek to analyze a particular aspect of this more rarely discussed issue in this paper: the establishment of specific communities of tariffed sex practice for $\mathrm{men}^{2}$ in Porto Alegre that includes discourse related to sexuality experiences and gender identifications.

Some aspects of the context of men's prostitution in Porto Alegre have already been traced. From 2004 to 2005, the groups Nuances and $G A P A / R S$, in a project called Pleasure also has its price, performed a survey of men in the metropolitan area of the city in places where prostitution is practiced (bars, saunas, and agencies). With a questionnaire applied to 106 men and 78 customers and observations in the prostitution locations, some social markers have been identified. Regarding their descriptions, " $90.6 \%$ were 18 to 24 years old; $70.8 \%$ self-declared as Caucasian"; " $38.7 \%$ finished high school". In terms of how long they had been engaged in prostitution, " $44.3 \%$ had been active from 1 to 5 years". Regarding customers, " $67.9 \%$ were between 31 and 50 years old"; "73.1\% self-declared as Caucasian"; "38.5\% finished high school", and " $41 \%$ had an undergraduate degree' (Nardi, 2006, pp. 50-60).

The analyzed theoretical overview that summarized the description of this group pointed to the need for studies in the gender relations field, which would be able to denature the subjectivity and masculinity constructions in relation to tar-

\footnotetext{
Although we use "prostitution", we comprehend the phenomenon with the idea of "tariffed sex" (Pocahy, 2012). The choice for this word is an attempt to destabilize the "prostitution" notion as linked to money negotiations - focusing on the plurality of changes that happen in the dynamic in question.
}

iffed sex. When intertwining issues such as subjectivity, masculinity, and tariffed sex, it seems appropriate to consider the personal narratives dimension and the speech linked to its construction in the social tissue. Therefore, language is central, and it is understood as a reality maker in which ways of existence are performed - a process of repetition and the regulation of actions, gestures, the behaviors that indicate the possibility of the subjects to occupy legitimate or illegitimate places in the social field, and gender and sexuality relations that establish a part of this construction (Butler, 2002). These relationships are linked to rules forged in repetition and regulation, socially created aspects (Foucault, 1987) whose critical analysis gives aid to understanding social categories, such as man/woman and the masculine/feminine field, as performative manifestations (Butler, 2002). Therefore, sexuality is here understood as a social phenomenon (Foucault, 1987) as well as the exercise of masculinity and its connection to the current definition of being a man (Badinter, 1993; Caetano, Silva, \& Garay-Hernández, 2015; Connell \& Messerschmidt, 2013; Kimmel, 1997; ViverosVigoya, 2011).

In this field of discussion, we can consider that the process of becoming a man or woman works through "cultural coordinates in the subjectivity constitution" (Madureira \& Branco, 2007 , p. 82), as it is connected to assumed positions in the cultural panorama that are established for life (Louro, 2011). Subjectivity is here understood in a socio-cultural perspective as a process in constant development (Kirschner, 2010) and as an intersubjective construction that happens through narratives. In these constructions that happen through narratives, gender and sexuality appear to have special importance, and these aspects are the tonic of this paper. We consider the premise that there is a social organization of power inherent to these relations (Scott, 1995) that transcends biological differences and highlights the constitution of the person by the powers, and in the logic opposed to naturalization/essentialization and binarism, as these symbolic dimensions happen in private contexts, they are therefore changeable (Piscittelli \& Si- 
moni, 2015). Gender and sexuality, taken as operational concepts, make visible questions that are situated in daily experiences that demand situated and, therefore, partial analysis (Haraway, 1995). To consider this notion of situated knowledge, we propose an exercise of closely examining gender and sexuality perspectives to the model of communities of practice, as in the analysis proposed by Paechter (2003).

According to Wenger (2001), the notion of community is organized by three integrated axes: mutual commitment, joint action, and shared repertoire. These notions allow us to understand the process of creating a community as contextual and coherent relations of practices, identifications, and learning. To Wenger (2001), such aspects do not suppose homogeneity, being composed in a relation of complementarity or situated partiality. Mutual commitment addresses a web of meanings that are mutually negotiated. It is based in a process of working together and, therefore, of keeping communities through relationships and the negotiation of group processes. The second notion, the idea of joint action, is defined by practices resulting from mutual responsibility relationships in a community. However, the third aspect, shared repertoire, addresses a historical dimension of mutual commitment, conceived in a group by aspects such as shared speeches, concepts, artifacts, and styles involved in community practices.

Therefore, we start with the communities of practice concept as a phenomenon related to building and keeping meanings and understandings in the scope of tariffed sex practiced by men, considering that this dimension is not dissociated from social markers of difference or from the effects of the capitalistic ways of living (Streek, 2012) clearly implicated in these processes. Gender and sexuality are interpreted as performative instances, which are expressed in bodies, situated and indicative of certain regulative fictions (Butler, 2002), based on power relations (Scott, 1995), and which manifest in repetition and regulation processes (Foucault, 1987). Hence, we propose to analyze the scope of the portrayal of communities of practice in the context of tariffed sex practiced by men in Porto
Alegre. Specifically, we analyze communication and discursive aspects related to the exercise of sexuality and gender identification.

\section{Method}

The problem cited in this paper and the dimensions of the realities insert this study into a qualitative approach, sensitive to researcher experiences and to the thoughts brought by people in the field. Therefore, we used an approach inspired by grounded theory (Charmaz, 2009). According to grounded theory principles, the process of making a study begins by formulating questions open enough to allow empirical interpretations to give opportunities for research directions (Charmaz, 2009). This method comes from a system that consists of returning and discussing research goals with every new collection, constant (re)organization of collected material, information coding and classification, and results systematization in memos.

As a result of this approach, this research changes during its course, especially regarding the places visited. We added sites as the interviews happened based on participants' indications, enlarging the field of observation and the references used (and also changing through the process of contact to address themes not previously planned, brought by the experiences of the participants), until getting an analytical articulation of theoretical and empirical quality that enabled us to answer the questions proposed, especially regarding the building of communities of practice as presented by Wenger (2001).

Even though a web of places was mapped in this research - a street, two saunas, two bars the analysis of this study was developed based on dialogues with men from two specific places in Porto Alegre: a bar and a sauna. This choice was due to those places being the most frequented by the web of participants in this research and because it joined participants who also developed practices in other contexts. Data collections were performed by visiting these places of tariffed sex; observing what happened throughout 2015; establishing a field diary with a descriptive register, which also had informal conversations 
with people in this environment; and interviews. Two interviews were conducted with men who had manager positions, four with men who practiced tariffed sex in the cited places, and two others with men who also practiced tariffed sex but had developed their activities outside this circuit (one using apps for sexual encounters and the other who catered only to specific customers, acquired in his past during street prostitution). The inclusion of these last two participants was due to the suggestions of other participants.

All participants were contacted by a first key informant, a manager of sexual health, or by intentional sampling known as snowballing (Flick, 2009). Beyond the many conversations and written field dairies, the eight interviews followed a narrative perspective. According to Bauer and Jovchelovitch (2002), the narrative interview is a method of deep interviewing that demands the interviewer avoid influence over participants' words to prevent any obstacles to the story. Planning a generational question or initial topic that starts the interview is one of the technique's fundamental processes (Bauer \& Jovchelovitch, 2002; Flick, 2009). For this study, the question posed - and which was the subject of an approximation of the narrative terms through the interviews - was: How did you start and how has your path in the context of tariffed sex been developed? We did not set a specific duration for interviews, as suggested in specialized literature (Bauer \& Jovchelovitch, 2002; Flick, 2009), but the average time was 40 minutes. The interviews were audio recorded and transcribed for later analysis, and the participants have fictional names.

The concurring use of grounded theory and discourse analysis is already consolidated in current studies. As in Reiner Keller (2005), the systematization of these approaches may account for an oscillation present in the qualitative analysis of human sciences, which range in extremes from macro-discourses to language analysis in excessive, particular uses. Accordingly, Charlotte Burck (2005) also explores the connections between grounded theory, discourse analysis, and narrative analysis, understanding that they allow a systemic and contextual point of view.
From this discourse analysis, some elements have emerged - based on data - which address the idea of communities of practice, connecting the axes of mutual commitment, joint action, and shared repertoire with practice concepts in which aspects such as meaning negotiations, learning processes, places, and limits were listed.

\section{Results and Discussion}

The results, emphasizing the processes of the establishment of communities in the context of men's tariffed sex, made it possible to understand this phenomenon through the following groups: Men devoted to Tariffed Sex (MPS); MPS and Managers; MPS and Customers. Although participants in this study belonged to different places (Sauna/Bar) with their own particularities, they made it possible to have an integrated analysis. Thus, this analysis proposes to emphasize the Sauna and Bar locations in its cross-sectional aspects, as distinguished from discussions that were sometimes used with participants practicing tariffed sex at home and by cell phone apps.

We established the MPS category as representative of Sauna/Bar locations due to community connections that will be analyzed later, which seem to be related to the tariffed sex circuit of MPS (which involves, for many of them, an itinerary that includes both places). These relationship dimensions appeared in the field and in the interviews and can be interpreted according to mutual commitment, joint action, and shared repertoire - noted in this study as the central axes in the concept of communities of practice (Wenger, 2001). The researcher as a specific spectator and situated in the interviews is not considered detached from such an understanding but seeks to comprehend this established relation (both in interviews and field diaries) as possibly offering contextual and partial analysis of the targeted phenomenon. For that reason, we seek to develop a theory based on field data that answers to the peculiarities of the circuit developed by the researcher (Charmaz, 2009) through informers and using the appropriate theoretical choice. 
Table 1

Characteristics of the Participants

\begin{tabular}{|c|c|c|c|c|c|c|c|c|}
\hline $\begin{array}{l}\text { Information } \\
\text { declared }\end{array}$ & Ezequiel & Daniel & Joel & Samuel & Jonas & John & Manager & $\begin{array}{c}\text { Party } \\
\text { Promoter }\end{array}$ \\
\hline Race/color & Black & white & mixed & white & white & white & white & white \\
\hline $\begin{array}{l}\text { sexual } \\
\text { orientation }\end{array}$ & heterosexual & heterosexual & heterosexual & heterosexual & heterosexual & homosexual & $\begin{array}{c}\text { not } \\
\text { declared }\end{array}$ & gay \\
\hline schooling & high school & $\begin{array}{c}\text { elementary } \\
\text { school }\end{array}$ & $\begin{array}{c}\text { elementary } \\
\text { school }\end{array}$ & $\begin{array}{l}\text { incomplete } \\
\text { higher } \\
\text { education }\end{array}$ & $\begin{array}{l}\text { middle } \\
\text { school }\end{array}$ & $\begin{array}{c}\text { high } \\
\text { school }\end{array}$ & $\begin{array}{c}\text { not } \\
\text { declared }\end{array}$ & $\begin{array}{c}\text { higher } \\
\text { education }\end{array}$ \\
\hline age & 50 years & 23 years & 18 years & 25 years & 30 years & 26 years & $\begin{array}{c}\text { not } \\
\text { declared }\end{array}$ & $\begin{array}{c}\text { not } \\
\text { declared }\end{array}$ \\
\hline $\begin{array}{l}\text { most recurrent } \\
\text { term in the } \\
\text { activity }\end{array}$ & sex worker & boy escort & boy escort & boy escort & boy & boy escort & $\begin{array}{l}\text { manager } \\
\text { of a gay } \\
\text { house }\end{array}$ & $\begin{array}{c}\text { party } \\
\text { promoter }\end{array}$ \\
\hline clients & $\begin{array}{l}\text { recurrent } \\
\text { clients }\end{array}$ & $\begin{array}{l}\text { eventual } \\
\text { clients }\end{array}$ & $\begin{array}{l}\text { eventual } \\
\text { clients }\end{array}$ & $\begin{array}{l}\text { fixed } \\
\text { clients }\end{array}$ & $\begin{array}{l}\text { fixed } \\
\text { clients }\end{array}$ & $\begin{array}{l}\text { recurrent } \\
\text { clients }\end{array}$ & & \\
\hline $\begin{array}{l}\text { time in tariffed } \\
\text { sex activity } \\
\text { (Approxi- } \\
\text { mately) }\end{array}$ & 20 years & 10 years & 3 months & 5 months & 5 months & 6 months & 30 years & 10 years \\
\hline $\begin{array}{l}\text { activity } \\
\text { beyond } \\
\text { tariffed sex }\end{array}$ & $\begin{array}{c}\text { government } \\
\text { employee }\end{array}$ & none & none & $\begin{array}{c}\text { family } \\
\text { company }\end{array}$ & none & $\begin{array}{c}\text { graduate } \\
\text { student }\end{array}$ & & \\
\hline $\begin{array}{l}\text { Place of } \\
\text { activity }\end{array}$ & $\begin{array}{c}\text { network } \\
\text { of the } 1980 \text { s } \\
\text { (Street) }\end{array}$ & $\begin{array}{c}\text { starts on the } \\
\text { Street - go to } \\
\text { Bar }\end{array}$ & Bar & Bar & Sauna & Mobile Apps & Bar & Sauna \\
\hline
\end{tabular}

The first analysis point, the relational MPS's area, relies on a relational dimension mainly linked to "making ethics". For example, the maintenance of regular prices, which happens mainly in the Sauna context, along with notions of secrecy and anonymity (in relation either to other men devoted to tariffed sex or general customers) are two of the main factors related to the notion of mutual commitment. As said by Jonas:

It is more like a deal among the guys there. They make a price and no one charges any less, you know, because then it happens that they go to the one who charged less and they leave a price more or less like that, from 100 to 80 reals, and this is the price. Between 100 and 80. So it is a standard for everyone, right? And there is no talk of charging less to make oneself better. Because, if so, if they get to know that, they make a mess... Because then it is dishonest. (Jonas)
The secrecy and anonymity configurations are present both by the use of fictional names (varying according to the place) in establishing of communicational closeness with customers restricted to places such as bars and saunas and in the refusal of any possible identification or depiction of aspects of other men's lives who are also devote to tariffed sex. The cartel configuration, consented negotiation by the group, reinforces the idea of mutual commitment. Moreover, this notion of mutual commitment is closely related to the masculine behavior of "gentlemen's negotiation". This dimension is repeated in situations in which there are arguments/retaliations due to tariffs changes without consent from the group, pointing to the use of force. In one of the observed places, a sauna, the retaliation role in case of a commitment break was led by one of the MPS. He had a strong presence in the place and was pretty expensive, using soccer jerseys 
after Sauna closed. He would start jokes that brought to mind games of power and fighting or had provocative conversations with other MPS.

Such behaviors point to traditional masculinity practices. Badinter (1993), in her social historiographic work, establishes how men's lives have been circumscribed by patriarchal arrangements connected to social norms and demonstrative exercises of strength and aggressiveness. She references characteristic rites of passage in many cultures in which "becoming a man" is a process of the identification of a new stature inside the community. The author makes evident that questions related to "being a man" are given a daily dimension by public proof. The field of masculinities into which Badinter looks is here understood as associated to Connel and Messerschmidt's (2013) and Kimmel's (1997) considerations, which point to the existence of certain expectations regarding men - some proof of strength, honor, and bravery. These aspects are daily confirmed by men and women in places such as schools, clubs, and in the family.

The sauna in which these interactions happened more frequently, either as jokes or provocations, was mainly a stage area, and on specific days, on one of its walls, there were soccer games presented. The way in which this space was built and the related maintenance, which also comprised architectural aspects, calls attention to what Welzer-Lang identified as "places for men" (2001, p. 462). He created the term to define the set of places and spaces that design the masculine universe, such as interaction groups at schools, clubs, cafes, or other communities stages of arduous combat regarding behaviors or characteristics that could resemble the ones traditionally related to women. In these spaces, homoerotism can be experienced in different degrees and dimensions and learning happens by suffering, as stated by Badinter (1993); they also allow the incorporation of organized knowledge into codes. The context of homo-socialization that exists at the sauna cohabits with this and other virility manifestations associated with heteronormativity and often flirts with factors such as exercise of violence, intrinsically related to group maintenance.
Other aspects appear as representative and intrinsically related, such as the notion of joint action. There is a perception regarding the Sauna that "it is the boys who make it work" (Jonas). Jonas's assertion demonstrates how the communication process allows thoughts of resistance processes, activities and assemblages that face possible explorations, referring to what Paechter calls "practice as local" (2003, p. 73). This notion, however, is less soft in contexts of bars, where Management is more active and opinionated regarding MPS. There, Management's detachment/approach seems to give an outlet to different ways of organization according to the context. Still performing what we understand as joint action by MPS, the question of approaching (linked to respectful and gentleman-like behavior) manifests in both spaces. However, the approach technique in the bar, where Management surveillance is more obvious, is more rigid and evident.

Beyond aspects related to the composition of this community of practice regarding mutual commitment and joint action, we see that these spheres are not detached from a shared repertoire in the context of tariffed sex. Aspects such as the exercise of codes linked to traditional masculinities (for instance, the use of certain aesthetics) and the discourse of "dowry" as representative of virility are connected to this axis. Inside this aspect, the restricted use of drugs is evident as strategy to control the masculinity and virility performances - such as gestures, looks, ways of walking, and sexual availability. The idea that the customer looks for affection and is guided by the lack of it seems to point to a discursive process we call "customer's desexualization", a game of power in which there is some protective disinvestment that sets the MPS away from possible identification with an idea of homosexual conjugality.

Other ways of experiencing tariffed sex show how the territory notion intervenes, implying ways of living, languages, and symbolic changes (Perlongher, 2008; Toneli $\&$ Perucchi, 2006). Two of the interviewed participants dressed themselves differently in relation to other MPS who were at the saunas 
and bars. Ezequiel (black male, approximately 50 years old, heterosexual, civil servant, low middle-class, and stable income), who did not often visit saunas or bars, identified himself as sex professional and performed at-home dates with his customers, indicated a different dimension from other men regarding tariffed sex in his life. Ezequiel's interview, which describes his tariffed sex as an activity with more of a technical perspective, shows a context in which, to be good professional, it is necessary to have a well-marked ethics dimension with little space for pleasure or affective slips:

The good professional tries to keep the customer, to hold the customer's attention, even because it's like what I told you, many customers referred me to other customers. And not the bad professional, the person will never see that character anymore. So, it's that thing, like I said, not sometimes, but the sex professional can act as some kind of psychologist, sure, with no formation, but that thing of listening and giving attention because there are many needy people in this business. That is when the mean-spirited and profiteers show up who take advantage of this to extort, to drug and to steal the person. These people want help because they have problems, they pay, but say: "I don't want to do it, I just want to take it all off of my chest; I want the companionship, to stay awhile at home or to go to a bar or the movie theaters". And I am a person with no mystery, who is patient in listening to others. Someone even told me: "You would be a good psychologist, a good psychoanalyst because you are patient and listen to people". And that helped me get many customers. (Ezequiel)

The constructive argument regarding the possibility of validation of prostitution as a performance of ethical demands uses the audience - the researcher - as possible way of approaching and gaining affirmation. The tone is professional and marks how the interviewer is in a very peripheral stage of appropriating the meanings of the practices in this community. To be a professional who listens is central in
Ezequiel's performance, thus while he implies a series of care demands in his performance, he understands tariffed sex as an action in which the sex and pleasure dimensions are worth attention in more a sense of controlling. Even if participants who showed up at the saunas/bars in this study repeated the perspective that what matters is customers' looks, to Ezequiel, the work scope supposes a negotiation in which a fair price is not measured by physical appearance or by affective dimensions, but by a more operational and restrictive view:

It's that thing, everything I said before. I say: “Look, I do this. Like, I don't have oral sex with men, in women I can consider, so I tell them that I don't do passive sex, and they accept it..." (Ezequiel)

In addition to the separation of the sexual interest dimension in name of legitimate technical work, Ezequiel identified separations among men who frequented the itineraries of tariffed sex in Porto Alegre. With attributions of "good professionals" and "profiteers" (or swindlers), he suggests investing in a trustworthy relationship with customers and a shared demand among the characteristics of a professional of this area. Ezequiel's positioning regarding tariffed sex, which takes into consideration a dynamic among customers, coworkers and "swindlers", is not detached from a specific notion of legitimate work. Ezequiel's "technical" answer of tariffed sex may address a notion of the moral desirability of the professional activity in question, which manifests an affective closeness controlled by a professional notion of listening, as well as generational aspects suggesting a more restrictive performance regarding sexual activities.

To John, who did not take part in the sauna/ bars contexts either, but who used cell phone apps to practice tariffed sex, this recognition dimension was also different. John was a young graduate student, Caucasian, the only participant who was a self-declared homosexual, and from a wealthy family. For this participant, tariffed sex was more related to the pleasurable experience of being desired, having pleasant sexual intercourse, and life experiences: 
- In my case, it was just that, I just wanted to know how it was. ... Obviously, I'm not tall, strong or well-hung... because the general ad of rent boys (RB) is... well-hung. It's how many centimeters. And, for me, it's really something like: Man, come on! It's bullshit... So, I always make this clear while talking. Like, if you're looking for somebody to fuck like crazy... that's not me. I'm more like... affection, talk... have sex, of course, but not that mechanical thing. And obvious$l y$, there are the ones who ended up wanting to meet me; they were interested. Not in the "let's fuck like crazy" way. One thing I find interesting, funny, is that there are no passive $R B$, you know, only active ones. I guess they would do better if they were passive.

-Do you think so? Why?

- I don't know, I think it's because, generally, being passive is less one thing... I don't know, physical, or one thing about sex only, but being active is more like: oh, it's a butthole, that's fine. Being passive and feeling pleasure, at least for me, is not like: hey, how many centimeters do you have? However, if I like the person, you know...

In this narrative piece, John vocalizes questions that distance him from the community context established by other MPS. In addition to the pleasure dimension guiding his tariffed sex itinerary, John separates qualitatively his way of positioning himself in tariffed sex in relation to other men who are also involved in it. The reflection on his appearance, different from the imagined rent boy as a person of hyper-mannish performances, is connected to the comprehension that the type of sexual intercourse he offers is not "mechanical" or "crazy" (without affection and intense), but it is a moment of fondness and gentleness, of "cute sex" as he described it in another narrative piece. Moreover, there is a process of ambiguity between being or not being a rent boy when he repeats in his speech that being "passive" does not have the same implications as being "active". John seems to turn away from tariffed sex as a technical dimension, highlighting the pleasure and displeasure involved.
The comprehension that MPS's expected image is hyper-mannish and the sex of other MPS as destitute of affection works as a way to distance himself from this community of practice. This differentiation process does not manifest in this sphere only, but it is also shown in the use of the terms indicating the activity. When asked how he named what he did, he said:

Like: "What do you do, and so...", not using any other specific term... or: "Oh, you're an RB. RB is more common". I only say $R B$ or other kind: "but, $R B$..." RB what? Then, I: "No, rent boy". Because not everybody knows the initials. But the name never... it didn't call my attention... The other RBs use it, so do I... (John)

The use of the term "RB" seems to be an answer to customers' approaches or to a certain more common use in Porto Alegre as a way to refer to men who engage in tariffed sex. However, even if the term "RB" is also used in the Bar space, the way of using it in this way is more appropriate among the sauna's and bar's MPS; the differentiation refers to territory but not to John. The use of the terms "RB" and "boys" in the bar and sauna contexts, respectively, is contextual and functionally refers to the places in which tariffed sex is exercised, but it also guards resemblances to community of practice ${ }^{3}$. The existence of men who move with higher probability from these normative sets (ethics in relation to the "house", coworkers and customers) is often linked to social markers that position certain subjects in situations of privilege. Social markers of difference, such as skin color, class, and education, put these subjects in a better or worse condition in this community context. From field diaries and itineraries noted during interviews, the more diligent men in the places were the ones more vulnerable to reprisals in the case of breaking conduct. Otherwise, the men who had more fixed customers (and who could

3 These address a longer urban itinerary that is not a goal in this paper. In the methodological process we chose, I went to five places that constitute a network of socialization beyond the bar and the sauna - here cited as prototypical places. 
therefore frequent the place less) were often Caucasian and/or had a higher education and/or had a more stable financial condition - giving them more mobility, financial profit, and thus more safety.

If these aspects are performed by men in an exercise connected to what Butler (2002) exposes, it is important to focus on "being man" and ways of exercising masculinity. Mara Viveros-Vigoya (2011) addresses this question, understanding that it is necessary to conceive specific contexts and the various social markers involved, such as gender, "race", and sexuality, for example, which allow questions about the many possibilities of being a man dynamically. In very diverse contexts involving very young people, such as schools, studies point to differences in masculinity performances and in attributions of "being a man" that are linked to difference markers, such as color and gender dynamics (Caetano et al., 2015).

From these considerations, we understand that the sauna and the bar in this paper are the community core in a way that other MPS (John and Ezequiel) exemplify more peripheral positioning in relation to the tariffed sex circuit described. These two men shared some but not all elements involved in this practice. Even if they recognize the existence of bar and sauna itineraries around the city and understand the symbolic aspects involved (such as the use of the terms), their experience is guided less by subsistence (in relation to most MPS in those places). Moreover, identification and sexual practices discourses seem more extreme, placing Ezequiel closer to a more traditional masculinity (more restrictive regarding the type of performances in sex with his customers) and John closer to a sexuality exercise guided by his pleasure and identifying as homosexual (performances in sex with customers who please and satisfy him).

Another system understood and community of practice also happens in MPS/Managements communication dimensions. This community may feature the use of joint strategies that also refer to maintenance of negotiations in tariffed sex locals. The comprehension of mutual commitment in this sphere is manifested with MPS's wellbeing in the sauna and in the bar. If in the bar, the process of assuring wellbeing occurs through daily dinners and drinks to "relax" before customers' arrival; in the sauna, the idea of wellbeing is present by the available parties: "The ones who work with this want to be eating, drinking, watching the shows and having fun for free. The ones who pay for all this carnival are the customers. The boys enjoy it" (Party promoter). The strategy developed by the house Management to MPS's customers works for Jonas, one of the MPS in the sauna. The parties in the sauna, especially during the weekends, have a low profit but are fun. In addition to the idea of fun as a maintenance process in relation to MPS/ Managements, questions about the prohibition of illicit drugs, robbery, trafficking, and secrecy arise as aspects that address ethics related to tariffed sex in those locations.

Understanding this community by the joint action question, we can see there are strategically situated tactics to enable encounters. One of the boys who specifically attends the sauna points to architectural disposition - specifically the exhibition of heterosexual movies - as joint trick:

Now I have a fixed customer, and he is very nice. . . But sometimes you get some who are very difficult. Looks, everything. You see a little of everything. Without mentioning that sometimes there are some "mummies" there. And then, to do the job there is complicated... . . . It's... normally there are hetero movies in the room, so you see some porn and you are good to go. And then you get it going. But in the beginning it's difficult, to get it up, to make it work... (Jonas) Even though the MPS's practice was a "carnival" to the sauna management, Jonas points to some difficulties and setbacks related to dealing with customers. Tariffed sex, with more or less intensity, is about negotiations in which desire is present. This crossing, however, attempts to establish sex as an exercise of socialization and eroticism that is not "natural". Desire, according to Bensusan (2006), is circumscribed by social and historical constructions. For that reason, it is intrinsically related to political processes 
(Bensusan, 2006; Pelúcio, 2014) in which the connection between what is considered "erotic" and people's histories, as well as possibilities of reflection on social discourses, allow the understanding of bodies as socially implicated platforms (Bensusan, 2006). Another aspect related to joint action are the dinners and thematic parties, at which it is possible to see and bid on MPS. This type of event happens especially in the bar and includes assessment apparatuses and forms of honoring men's beauty and physical attributes. In addition to this aspect, figures in the bar indicate appropriate MPS for specific customers according to personal characteristics identified by Management (enjoying dancing, going to parties, considered by the Manager to be more "intelligent" or have more pleasant physical attributes, etc.).

It is possible to interpret this communication context of MPS/Managements as an aspect of shared repertoire in a special control/protection discourse. Practicing these activities in closed places allows advantages such as safety and constant circulation of possible customers for MPS but also makes them subject to the norms of the places they attend. To management, the possibility of having MPS circulating improves the sale of drinks, the renting of rooms and attendance in the spaces. This negotiation, based on the control/protection idea, seems strictly linked to "pedagogical" processes (Louro, 2008, 2011) in which the shared repertoire, as well as in other dimensions, is not static but in constant construction. In the bar, it is possible to observe close rules regarding the MPS's circulation: men must leave one by one to have a smoke, must be clean, and must be dressed appropriately, should not be using drugs, etc.

By conversations and practices, ways of dressing and behaving - as in the trottoir around the house - the articulation context between Management and MPS still repeats a certain logic that "what customers look for is a guy with a big cock and who is mannish, since sissies don't like little girls" (Manager, Bar). This aspect is intrinsically related to involved pedagogical relations, but we must note that this stereotyped discourse about what customers look for is not monologi- cal, but polyphonic, such as John highlighting his physical attributes and sexual practices with customers differing from normative idea. In different moments of the interview, he referred to himself as "whore". Even if in an ironical tone, it reinforcing an idea of other possible identifications in the exercise of men's prostitution. In this aspect, we can notice how a territorial dimension also influences in the maintenance of a community of practice.

The control, the vigilance, and the guardianship happen in both places and are manifested as connected to essential interpretations about "being a man" in tariffed sex but also demonstrate that this shared repertoire is not a stable phenomenon, but contextual, which influences treatment - punishment among them. The guardianship aspect in the bar is related to an idea that part of the men who attend was "taken away" from drugs and streets, and needs to be directed by the manager. In the sauna, this type of control and care is more related to MPS's internal group. However, in the sauna, the notion of vigilance is also manifested, as a Party Promoter shows, and nurtured by the discourse that tariffed sex is intrinsically linked to the idea of addiction, greed, and bad character and that, therefore, demands extra care from the customers and management toward MPS who attend the place.

... as the boys, as we call them, they are intelligent guys who are there to make some money. They have the same capacity to be a salesman, a real estate agent, and a stockbroker. But I don't believe in fidelity. I don't believe in the fidelity of rent boys. Prostitution is addictive; it's the way of seeing, of understanding and communicating, prostitution is like an addiction to cocaine, to crack, to cigarettes, to alcohol. Because... when the guy, the young one, enters the sauna the first time for prostitution, and a customer says "I'm going to get this one, he is naïve, not a prostitute yet, I'll marry that guy". This sauna owner once told me that when this guy gets inside there, his soul is already a whore's. So, even if someone finds him and takes him away from this life for the first time, he keeps mentally, spiritually, and 
bodily being a homosexual. But not only a homosexual, a homosexual for whom money comes first. Therefore, he's not going to give up on being a rent boy while his body and beauty allow ... (Party promoter)

In this speech, there are some aspects that show the plurality of discourses influencing in the relation between management and MPS. MPS's capacity for negotiation, said to be very potent, is linked to the use of this potential in a deceptive way with customers. Moreover, there is also a fidelity discourse that shows ambiguity in the MPS's performances in relation to customers (even in Management discourse). Fidelity in that moment is posed in contraposition to prostitution (taken as performing connected to addiction) and is shown as a desirable aspect and points to ambiguity related to tariffed sex. Even in a sauna context and with the management position as guarantor of tariffed sex discourses, a moralist perception on MPS's practices is present. Being MPS in this point of view shows an aspect of sexuality exercise connected to the manifestation of certain intimate, animistic, deep, and fundamental truth, as discussed by Michel Foucault (1987). The sauna manager points to MPS's practices in a pathology field in which the bad character and infidelity are manifestations of this "soul of a whore". In this context, the man whose soul "is already from a whore" is understood as having homosexual instrumentation through the capacity of sale and guided by greed; he is determined to be this way. These classificatory efforts seem close to the constitution of abnormality as way of repeating a normality idea, even in the dissident context of sexual commerce. Such logic is corroborated by the Party Promoter's testimony when he says: "They are specialists. In bed, they make you believe that you are Delilah and he is Samson. Or that the customer is Madonna and he is Jesus Luz".

The difference listed by the participants regarding this gay/MPS dimension also makes reference to a series of behaviors in which the approximation of feminine conduct in relation to the customer and in the sexual encounter performance is determinant:

... there's a difference between a rent boy that I also consider gay and gay who is a rent boy, It's a difference by the behavior because the gay has a little more affected behavior. The gay looks in a way that the boy doesn't. The boy talks about a macho conversation, goes to bed with another macho and it doesn't matter what happens, it's only a matter of values. (Party Promoter)

To the party promoter, MPS's personal practice is circumscribed in a quite restrictive manner. MPS are "machos" who obey a conduct of pleasure detachment that guarantees a certain behavioral composition, essentially different from the "gay" and guided by values. That is, sex performance in this context, and especially to "machos", is justified by consumption and negotiation of involved values. Additionally, the use of terms referring to the feminine - which are particularly linked to demeaning contexts in tariffed sex - not only is present in this narrative but is also an aspect that will be reexamined in the next description of community of practice MPS/Customers.

In the MPS/Management community of practice, the punishment possibility is present, and it is part of the relationship and strongly connected to the territory dimension. Punishment may be observed via "suspension" as it happens in the bar context. Considering that the use of apps and the Internet is avoided for the bar's MPS, which is indicated as protective (being there in person is considered a way of guaranteeing anonymity), encounters with customers seem to be detached from the bar's daily routine. For that reason, the choice of punishment by suspension, which is conducted by the bar's Manager, seems effective, as it can stop encounters with customers. However, this is a much more effective punishment in the case of men who have certain difference markers (Brah, 2006), such as being economically less favored. Joel, for instance, was reprimanded for some period for trafficking in the bar and noted difficulty in establishing contact with customers, resulting in 
a drop in monthly income. Even though access to the trafficking experience was used as a way of raising Joel's income, by contrast, Jonas did not have this issue because he did not need to appeal to other means of making money due to the stability of fixed customers and his family's income. For this reason, this system of who can be punished is also crossed by other vectors, reinforcing the idea that being a "whore" supposes plurality (Perlongher, 2008) and not a homogeneity in its practices.

The last dimension of community of practice analyzed in this paper is the articulation of MPS/Customers. Regarding the mutual commitment notion, we understand that there is a treatment or etiquette linked to the seduction and approach process. This type of etiquette, which features, for example, a certain order in the approach (each one of the MPS has their time for conversation and negotiation assured without the interruption of other MPS), is extended by assuming confidentiality and anonymity. In addition to this dimension, questions linked to the joint action notion make us pay attention to the maintenance of the idea that customers have more control or power in negotiation. This idea that customers have more power, manifested in the approach and in the communicational process, is reinforced by MPS in their interaction with customers but not in the relationship with other MPS in which the ideal of virility needs to be reinforced with allusions to representations of a theatrical concession of power to customers, as the latter rests in the "macho" (or in the one representing him). This power relationship is even more complex when we analyze the many dimensions involved, such as MPS who choose customers they find appropriate, scale their profits and possible problems, and often have knowledge of a previous situations through internal conversations among MPS. This aspect is particularly evident in veteran MPS in the house, as noted by Jonas:

. . they already know everybody who will, they are form the area, so they'll go to one, go to another. . . they already know that world, they know the ones who pay, the ones who have money, who will not fool you... I already know some guys who are there just trying to fool you... and there are others that the guys say: No, that man pays well, that other one doesn't, with that other one, just in last case... (Jonas)

This relation is not conflicted, as the more MPS have power over the relationship and the possibility of choice, the more a discourse of essentialization regarding greed and bad character seems to be present. In another way, the joint action, which can be taken by the negotiation process and tariffed sex performance, may generate an unforeseen dimension of relationship that, in addition to being contradictory, is also full of ambiguities. It is the case of fixed customers who seem to demand both affective and time dedication not foreseen by some MPS:

For as long as I can remember, I think there's something missing in their lives, and they look for a more affective thing, I don't know... I think they crave a relationship. I think they don't go there looking for sex only. They go there to meet someone because that's where they go. Then, they want to transform that into a relationship. Just like this fixed customer of mine, I could never imagine that he wanted to go out with me; now he calls me every day. (Jonas)

Inside this panorama, part of the shared action is especially noticeable when confronted. Some customers can be observed in this position that escapes the rules of the "house". This is the case of one of the customers from the bar, recognized for paying large amounts of money and whom many MPS desire. Negotiation with this customer seemed difficult, mainly because he talked openly of practices in which MPS performed activities related to positions from the "passive" scope. One of this customer's demands, as noted by the Manager and an employee of the bar, was to shave MPS's buttocks before "giving the butthole" (Manager, Bar). There seems to be a certain ritualistic dimension in this practice, which extended to the relationship field in the bar. This customer, who boasted his sexual activities with the men of the Bar and called MPS with whom he had encounters "my woman", showed that the break of this negotia- 
tion in the shared action scope opposed the virility and masculinity maintenance traditionally associated with MPS. This activity, however, is not one-sided. In discussions at the bar it is possible, even if rare, to see MPS calling customers "fags" in an aggressive and demeaning way.

The use of terms referring to the feminine does not stand out as only a strategic form of aggression, nor does it occur only among the sauna/bar locals. John, the participant who met customers by cell phone apps, also used the name "whore" to describe specific situations of tariffed sex in which a subservient position was on the agenda. One night, arriving at a building in a high class area of the city, John was directed by the doorman to enter by the service elevator:

- I find it interesting that you put it that way, to the guy who answered you...

- I wonder if he knows I'm a whore.

- It's because... that day, he sent me to the service elevator, then I was like... I didn't get pissed, but like: service elevator? Get it? ... So I was like... hum, I'm here doing my job. Who are the other people he tells to use that elevator? (John)

The terms that refer to the feminine, or are connected or representative of demeaning features or situations, point to the vigilance logic that permeates the studied places, as well as possible conflicts involving legitimate ways of being a man in these places and also outside them. This anxiety, generated by the feminine closeness, is present in many studies (Kimmel, 1997; Torrão, 2005; Welzer-Lang, 2001) and is contextually present here. To Perlongher (2008), for example, the dimension of the "whore's" danger of effeminacy is worthy of attention and is also present here. This composition makes us pay attention to masculine/feminine hierarchies as experiences related to tariffed sex, a feminized body as violation and subaltern spaces (Gregori, 2003). Other studies also note that masculinities are intrinsically related to behaviors that use strength and specific means of experiencing sexual intercourse (Connell \& Messerschmidt 2013; Kimmel, 1997). In this context, institutional intersections related to these gender and sexuality expectations take subjects who intuit certain ways of being masculine that can be manifested by estrangement from life dimensions considered to belong to the feminine field (Caetano et al., 2015).

This aspect gives rise to thoughts of other experience dimensions between MPS/ Customers, the shared repertoire. We can interpret the notion of shared repertoire by the esthetics involved in being MPS/Customer. Certain images of the possible customer or possible MPS that were shown by the researcher in the field make us pay attention to a repertoire of this identification esthetics. MPS esthetics can include a youthful look, the wealthy clothes of an upper class gentleman, the strong body of an athlete, or a more street 'rascal' appearance. The researcher position, which holds a certain ambiguity regarding this issue, is perceived in different ways: as possibly one of the MPS by older men or as a possible customer by MPS (as one MPS told me: "Why are you dressed as a customer?"), which clarifies the questions of this dynamic. Additionally, it is noticeable that the esthetic dimension in the process of "hunting" is not one-sided and involves both MPS and customers. If MPS put themselves in a rascal, good shape, or rapper esthetic, customers' expensive clothes and tables full of Red Bull seem to follow. As said by the party promoter and manager of one sauna regarding his interpretation of the functioning logic of these places:

Everyone who goes to a butcher's wants some fresh meat, and I see it that way. I don't see people as meat, I see people with affection and love because I'm a Catholic and I always try to help my peers. But this is life, everybody wants to shop and the ones with money always get the best. (Party Promoter)

\section{Final Thoughts}

We tried to analyze the set of tariffed sex communities of practice of men in Porto Alegre, considering the discursive articulations related to sexuality exercise and gender identification. The relations interpreted as part of these dimen- 
sions, which in MPS's cases require analyses regarding approach, secrecy and anonymity logic involved, negotiations on the cartel values, and use of strength to establish these relationships, makes us pay attention to intersections that show that the practices involved are immersed in discursive dimensions. Likewise, in MPS and Management community contexts, MPS's wellbeing maintenance, disposal of heterosexual movies, performance of events, and contacts in the tariffed sex locals, as well as punishment logics involved, are circumscribed by essentialist discourses about who the man is who is dedicated to the sale of moments of encounters. The dynamic linked to MPS and Customers, which shows some logic of etiquette and acting in which customers seem to hold a prerogative position over the negotiations, is evidenced by the breaks in this silent conducts: it is mixed with conflicting moments in which others' feminization discourse is a type of aggression.

The three listed dimension, MPS, MPS/ Management, and MPS/Customers, favor a view that we do not understand as dislocated from a common intention: maintenance of tariffed sex environments. However, we highlight that the established dynamics happen by vigilance and correction in a way that bodies worthy of legitimacy are formed and reinforced, and, thus, consumable within this relational spectrum. Concepts of essentialization discourses linked to a "whore's soul", to the notion that pleasure is genuine and legitimate and, to certain ways of being and looking by being "a little man" or "macho", emphasizes the power relationships in which classic stereotypes of virility and masculinity are present. Customers' "desexualization", as in moments when MPS highlight their customers mainly as a relationship of attention and companionship, is formed in a dimension in which a certain dissociation between sexual orientation and sexual practice operates as a means of reinforcing heterosexuality and virility.

\section{References}

Badinter, E. (1993). XY: Sobre a Identidade Masculina. Rio de Janeiro, RJ: Nova Fronteira.
Ballester, R., Salmerón, P., Gil, M. D., \& Giménez, C. (2014). Sexual behaviors in male sex workers in Spain: Modulating factors. Journal of Health Psychology, 19(2), 207-217.

Baral, S. D., Friedman, M. R., Geibel, S., Rebe, K., Bozhinov, B., Diouf, D., Sabin, K., ...Chan R. (2015). Male sex workers: Practices, contexts, and vulnerabilities for HIV acquisition and transmission. The Lancet, 385(9964), 17-23, 260-273.

Bar-Johnson, M. D., \& Weiss, P. (2015). A comparison of male sex workers in Prague: Internet escorts versus men who work in specialized bars and clubs. The Journal of Sex Research, 52(3), 338-346.

Barreto, V. (2012). "Vamos fazer uma sacanagem gostosa?" Uma etnografia do desejo e das práticas da prostituição masculino carioca (Master's thesis, Universidade Federal Fluminense, Programa de Pós Graduação em Antropologia, Rio de Janeiro, RJ, Brazil)

Bauer, M. W., \& Jovchelovitch, S. (2002). Entrevista narrativa. In M. W. Bauer \& G. Gaskell (Ed.), Pesquisa qualitativa com texto, imagem e som: Um manual prático. Petrópolis, RJ: Vozes.

Bensusan, H. (2006). Observações sobre a política dos desejos: Tentando pensar ao largo dos instintos compulsórios. Revista Estudos Feministas, 14(2), 445-479.

Brah, A. (2006). Diferença, diversidade, diferenciação. Cadernos Pagu, 26, 329-365.

Burck, C. (2005). Comparing qualitative research methodologies for systemic research: The use of grouded theory, discourse and narrative analysis. Journal of Family Therapy, 27(1), 237-262.

Butler, J. (2002). Cuerpos que importan - sobre os limites materiales y discursivos del "sexo". Buenos Aires: Paidós.

Caetano, M. R. V., Silva, P. M., Jr., \& Garay Hernandez, J. (2015). Ninguém nasce homem, torna-se homem: As masculinidades no corpo e o corpo nas práticas curriculares das masculinidades. Revista Periódicus, 2, 8-18.

Cantalice, T. S. T. (2009). Dando um banho de carinho! Os caça-gringas e as interações afetivosexuais em contextos de viagem turística (Pipa $R N$ ) (Master's thesis, Universidade Federal de Pernambuco, Recife, PE, Brazil). 
Charmaz, K. (2009). A construção da teoria fundamentada (J. E. Costa, Trans). Porto Alegre, RS: Artmed.

Connell, R. W., \& Messerschmidt, J. W. (2013). Masculinidade hegemônica: Repensando o conceito. Revista Estudos Feministas, 21(1), 241-282.

Flick, U. (2009). Introdução à pesquisa qualitativa ( $3^{\text {rd }}$ ed.). Porto Alegre, RS: Artmed.

Foucault, M. (1987). Vigiar e punir. Petrópolis, RJ: Vozes.

Gregori, M. F. (2003). Relações de violência e erotismo. Cadernos Pagu, (20), 87-120.

Grov, C., Rodríguez-Díaz, C. E., Jovet-Toledo, G. G., \& Parsons, J. T. (2015). Comparing male escorts' sexual behaviour with their last male client versus non-commercial. Culture, Health \& Sexuality: An International Journal for Research, Intervention and Care, 17(2).

Haraway, D. (1995). Saberes localizados: A questão da ciência para o feminismo e o privilégio da perspectiva parcial. Cadernos Pagu, 5(5), 7-41.

Keller, R. (2005). Analysing Discourse: An approach from the Sociology of Knowledge. Forum Qualitative Sozialforschung, 6(3), 1-13.

Kimmel, M.S. (1997). Homofobia, temor, vergüenza y silencio en la identidad masculina. In T. Valdés \& J. Olavarría, Masculinidades (pp. 49-62).

Kirschner, S. R. (2010). Sociocultural subjetctivities. Progress, prospects, problems. Theory \& Psychology, 20(6), 765-780.

Louro, G. L. (2008). Gênero e sexualidade: Pedagogias contemporâneas. Pro-Posições, 19, 2(56), 17-23.

Louro, G. L. (2011) Pedagogias da sexualidade. In G. Louro (Ed.), O corpo educado - Pedagogias da sexualidade. Belo Horizonte, MG: Autêntica.

Madureira, A. F. A., \& Branco, A. M. C. U. A. (2007). Identidades sexuais não-hegemônicas: Processos identitários e estratégias para lidar com o preconceito. Psicologia: Teoria e Pesquisa, 23(1), 81-90.

Medrado, B., \& Lyra, J. (2008). Por uma matriz feminista de gênero para os estudos sobre homens e masculinidades. Revista Estudos Feministas, 16(3), 809-840.
Melo Pedroso, V. A. (2015). Exercício ou exploração? O eterno dilema da sexualidade na prostituição feminina. Derecho y Cambio Social. Retrieved from derechoycambiosocial. com

Nardi, H. C. (2006). Poder sexo e o preço do prazer: Processos de subjetivação e prostituição masculina. In C. Almeida, C. Golim, \& F. Pocahy, Prazer também tem preço: Saúde, prostituição e cidadania. Porto Alegre, RS: Nuances.

Niccolai, L. M., King, E. J., Eritsyan, K. U., Safiullina, L., \& Rusakova, M. M. (2013). 'In different situations, in different ways': Male sex work in St. Petersburg, Russia. Culture, Health \& Sexuality, 15(4), 480-493.

Paechter, C. (2003). Masculinities and femininities as communities of practice. Women's Studies International Forum, 26(1), 69-77.

Pelúcio, L. (2014). Traduções e torções ou o que se quer dizer quando dizemos queer no Brasil? Revista Periódicus, 1(1), 68-91.

Perlongher, N. (2008). O negócio do michê ( $2^{\text {nd }}$ ed.). São Paulo, SP: Fundação Perseu Abramo.

Piscitelli, A. (2012). Feminismos y prostitución en Brasil: una lectura a partir de la antropología feminista. Cuadernos de Antropología Social, (36), 11-31.

Piscitelli, A. (2014). Violências e afetos: Intercâmbios sexuais. Cadernos Pagu, 42, 159-199.

Piscitelli, A., \& Simoni, V. (2015). Masculinities in times of uncertainty and change: Introduction. Etnográfica, 19(2).

Pocahy, F. A. (2012). "Vem meu menino, deixa eu causar inveja": Ressignificações de si nas transas do sexo tarifado. Sexualidad, Salud y SociedadRevista Latinoamericana, (11), 122-154.

Rios, R. R. (2012). Direitos humanos, direitos sexuais e homossexualidade. Amazônica-Revista de Antropologia, 3(2), 288-298.

Scott, J. (1995). Gênero: Uma categoria útil de análise histórica. Educação e Realidade, 20(2), 71-99.

Toneli, M. J. F., \& Perucchi, J. (2006). Territorialidade homoerótica: Apontamentos para os estudos de gênero. Psicologia \& Sociedade, 18(3), $39-47$.

Torrão, A., Filho. (2005). Uma questão de gênero: Onde o masculino e o feminino se 
cruzam. Cadernos Pagu, (24), 127-152. doi:10.1590/S0104-83332005000100007

Viana, N. J. Q. (2010). É tudo psicológico/dinheiro/ pruuuu e fica logo duro! - Desejo, excitação e prazer entre boys de programa com práticas homossexuais em Recife (Master's thesis, Programa de Pós-graduação em Psicologia, Universidade Federal de Pernambuco, Recife, PE, Brazil).

Viveros-Vigoya, M. (2011). Teorías feministas $\mathrm{y}$ estudios sobrevarones y masculinidades: Dilemas y desafíos recientes. La Manzana de la Discordia, 2(4), 25-36.
Welzer-Lang, D. (2001). A construção do masculino: Dominação das mulheres e homofobia. Revista Estudos Feministas, 9(2), 460-482.

Wenger, E. (2001). Comunidades de práctica. Aprendizaje, significado e identidad. Barcelona: Paidós. 